\title{
Intertextuality novel kcb 2 habiburrahman el shirazy with novel ksz \& z taufiqurrahman al azizy
}

\author{
Masrah Kurniawati ${ }^{1}$, Misriani Misriani ${ }^{1}$, Yessi Fitriani ${ }^{1}$ \\ ${ }^{1}$ Universitas PGRI Palembang, Indonesia
}

\begin{tabular}{l}
\hline \hline Article Info \\
Article history: \\
Received Jul $18^{\text {th }}, 2021$ \\
Revised Aug $12^{\text {th }}, 2021$ \\
Accepted Aug $30^{\text {th }}, 2021$ \\
\hline
\end{tabular}

\section{Keyword:}

Intertextuality

Structure

Novel

\begin{abstract}
The literary works that appear are not necessarily the work of the Authors, but they have read previous literary works. This study aims to determine intertextuality by looking at the similarities and differences in the novel Ketika Cinta Bertasbih 2 by Habiburrahman El Shirazy with the novel Kidung Shalawat Zaki and Zulfa by Taufiqurrahman Al Azizy using a qualitative descriptive method. Intertextuality plays a role in seeing a work that can be the basis for the creation of another work. The data sources of this research are Novel Ketika Cinta Bertasbih 2 by Habiburrahman El Shirazy published in 2007 and Kidung Shalawat Zaki and Zulfa by Taufiqurrahman Al Azizy in 2010. This research shows that intertextual occurs in the novel Ketika Cinta Bertasbih 2 by Habiburrahman El Shirazy with Song Shalawat Zaki and Zulfa by Taufiqurrahman Al Azizy because the theme, plot, setting, and message tend to be the same. The intertextuality of these two novels also has differences as the creativity of their respective authors. The research of these two novels can be deepened further so that the intertextual relationship between the two becomes clearer.
\end{abstract}

(C) 2021 The Authors. Published by IICET.

This is an open access article under the CC BY-NC-SA license

(https://creativecommons.org/licenses/by-nc-sa/4.0

\section{Corresponding Author: \\ Kurniawati, M., \\ Universitas PGRI Palembang, Indonesia \\ Email: masrahkepri@gmail.com}

\section{Introduction}

The emergence of a literary work cannot be separated from the presence of previous works to which writers have responded. In this case, the author does not necessarily create a work but responds first to a work. Wicaksono [1] states that no text is truly independent, in the sense that its creation and reading cannot be done without other texts as examples, and frameworks. Based on the results of the reception process, the author can take steps forward to produce a new work. The creation of literary works may be influenced by previous literary works. This previous literary work was used as a reference for later literary works. Authors can approve or deviate from previous literary works. Two or more literatures can raise the same theme, have similarities and differences. Then the intrinsic element emphasizes everything related to the story in the novel. Extrinsic elements are elements of the novel that are not as the part of the novel's story [2]. Every literary work contains moral principles with a specific sense that the author wishes to communicate to the reader. As a consequence, any piece of fiction includes a moral principle that the author wishes to express [3]. Novel Ketika Cinta Bertasbih (Book 2 dwilogy of soul builders) by Habiburrahman El Shirazy and subsequently written with As Ketika Cinta Bertasbih 2 and Novel Kidung Shalawat Zaki and Zulfa. Taufiqurrahman A1Azizy is an example of literary works that have similarities and differences. These two novels are based on a 
similar source, namely the lives of people who grew up in a pesantren environment. The two novels have different Narrativecenters.

The story in the novel becomes interesting thanks to the expertise of the author in composing words. The depiction of the story and social setting in these two novels is so real. This is inseparable from the social and educational backgrounds of the two authors who had studied at the Islamic boarding school. Habiburrahman El Shirazy studied at the Al Anwar Islamic boarding school, Mranggen, Demak and Taufiqurrahman AlAzizy studied at the Hidayatul Qur'an Islamic boarding school, Wonosobo.

The data in this study are in the form of review notes on the novel document Ketika Cinta Bertasbih 2 by Habiburrahman [4] with a thickness of 406 pages. The novel Kidung Shalawat Zaki and Zulfa written by Taufiqurrahman Al Azizy consists of sub-titles that are interrelated to form a plot to the end of the story. This novel was published in 2010 by [5] Press and is 403 pages thick.

The novel Saat Cinta Bertasbih 2 and the Kidung Shalawat Novel Zaki and Zulfa are very interesting to study intertextually, especially to find out how many elements in the novel Ketika Cinta Bertasbih 2 become a hypogram for the novel Kidung Shalawat Zaki and Zulfa. This is inseparable from his predecessor, Habiburrahman, who took up the theme. Thus, this study aims to describe how the intertextual forms in the novel Ketika Cinta Bertasbih 2 with Kidung Shalawat Zaki and Zulfa. With his style and storytelling, Taufiqurrahman wants to reveal life's problems in the form of efforts to find a life partner.

Two or more literary works with the same theme have similarities and differences. These similarities and differences indicate that each author has his own message that is conveyed through his work. Similarities and differences in several literary works can be analyzed by intertextual studies. This study is intended to examine texts that are considered to have a certain relationship with other texts so that it is possible for a work to become a hypogram for subsequent literary works. This statement is in line with the opinion of [5] which states that the basic principles of literature can be understood as a whole in relation to other texts that become hypograms.

The novel Bila Cinta Bertasbih 2 and the Kidung Shalawat Novel Zaki and Zulfa are very interesting to study intertextually, especially to find out how many elements in the novel Saat Cinta Bertasbih 2 become a hypogram for the novel Kidung Shalawat Zaki and Zulfa. With his style and storytelling, Taufiqurrahman wants to reveal life's problems in the form of efforts to find a life partner. This is inseparable from his predecessor, Habiburrahman, who took up the theme. Thus, this study aims to describe how the intertextual forms in the novel Saat Cinta Bertasbih 2 with the Song of Shalawat Zaki and Zulfa.

\section{Method}

This research is a descriptive qualitative research. Qualitative research is research conducted to examine various phenomena that occur in a society. Faruk [6] states that qualitative research is research that intends to understand the phenomena experienced by. [7] research subjects, for example behavior, perception, motivation, action holistically, and by means of descriptions in the form of words and language in a specific context that are natural and by making use of various natural methods.

The data source is in the form of a document from the novel Saat Cinta Bertasbih 2 works with Kidung Shalawat [8]. Intertextuality in the novel Ketika Cinta Bertasbih 2 by Habiburrahman E1 Shirazy and the novel Kidung Shalawat Zaki and Zulfa by Taufiqurrahman Al Azizy were carried out through library studies. The data collection technique in this study was carried out by document analysis techniques. The data collection technique in this study was carried out by document analysis techniques [9]. The data analysis techniques in this study are as follows. (1) When novel Cinta Bertasbih 2 and the novel Kidung Shalawat Zaki and Zulfa are read repeatedly. (2) All dialogues or narratives that contain structural elements in the two novels are recorded. (3) The data is analyzed according to the structural theory determined by the researcher. (4) Based on the results of the structural analysis, the researcher compared them by determining the structural similarities and differences between the two novels. (5) The data is analyzed according to the theory chosen by the researcher. (6) Based on the structural analysis of these two novels, the researcher analyzes the intertextual. (7) Once described, the data analyzed. (8) The results of the data analysis are concluded.

\section{Results and Discussions}

The novel Ketika Cinta Bertasbih 2 is a continuation of the novel Ketika Cinta Bertasbih [10]. Nurgiyantoro [11] which tells the life of people who are raised and educated in Islam. The story of Ketika Cinta Bertasbih 2 
tells the story of a girl named Anna who is the daughter of a kiai who owns an Islamic boarding school. Anna is described as a shalihah, patient, obedient, gentle, compassionate and very caring woman who is completing her Masters in Cairo. Anna's obedience is reflected when her parents request that she get married immediately, according to Anna. She married a man of her choice who had chanted her through her uncle in Cairo [10]. However, Anna's marriage to Furqon did not last long because a mistake Furqan made caused Anna to ask for a divorce. Even though her marriage only lasted six months, Anna accepted the fact patiently. But in the end, Anna's patient journey of life pays off. She remarries a man her father's choice of who turns out to be the man she dreams of.

The novel Kidung Shalawat [10] by Taufiqurrahman Al Azizy tells the story of Zaki, a kiai son who owns a simple Islamic boarding school in Java. Zaki, who was only raised and educated in his father's simple Islamic boarding school. is a pious but innocent man. Zaki's innocence is illustrated when he is easily framed and slandered for raping Ivon who is a friend of Zaki's fiancé, Zulfa. Zaki and Zulfa have been arranged by their parents Since they were in the womb. The slander of the rape caused Zaki to be arrested and Zulfa broke off the engagement and chose another man. But at the end of the story, Zaki gets outside prisoners and an arranged marriage by his mother with his own adopted younger brother who has repented. The storyline in the Kidung Shalawat Zaki and Zulfa novel uses a solid plot even though it uses subtitles, the storyline is centered on the main character from beginning to end. The characters involved in the story in the novel Kidung shalawat Zaki and Zulfa are closely related to the main character. The characters in this novel are diverse, there are round characters and there are flat characters.

The theme of these two novels is that they both raise the life of the child of a kiai owner of a islamic boarding school in getting a life partner. The next similarity in terms of character and characterization is that there are similarities between Anna and Zaki, both sociologically and psychologically, both of them are children of a kiai, the owner of an Islamic boarding school who is pious obedient to both parents, including accepting a life partner who is the choice of their parents. Furthermore, the similarities of the two novels are in the form of setting, both place, time and social setting, namely most of the stories are centered in islamic boarding school using morning, afternoon evening, and night.

The next similarity between these two novels is that they both use a mixed plot. The plot of the novel Saat Cinta Bertasbih 2 begins with the memory of the character Anna to a man whom she knows as Abdullah. This one-time meeting made a deep impression on Anna that she hoped to be matched with this man. Then the plot moves forward, then in the middle of the story there are several stories going backward in the form of the memory of the character Anna, then the plot goes back to the end of the story. Likewise, in the novel Kidung Salawat Zaki and Zulfa, the plot begins with the memory of the character Zaki in his mother's story about her matchmaking since she was still in the womb. Then the plot moves forward, then in the middle of the story there is also a reverse plot and finally the plot moves forward to the end of the story.

From a piece of the statement above contained in the novel Ketika Cinta Bertasbih 2 by Habiburrahman El Shirazy with the novel Kidung Shalawat Zaki and Zulfa by Taufiqurrahman Al Azizy, the researcher saw similarities and differences. These similarities and differences will be discussed from the theme, plot, character and characterization, setting, point of view and mandate. The similarities that the researchers found from the two novels were the theme, plot, characters and characterizations, and setting.

The dominant difference that the researchers found in these two novels was in the center of the narrative and the message. The narrative center in the novel Ketika Cinta Bertasbih 2 uses a third-person storytelling center, while the narrating center for Kidung Shalawat Zaki and Zulfa uses a first-person storytelling center. Another difference between the two novels is in the characters and characterizations and plot. There are quite a lot of characters in the novel Ketika Cinta Bertasbih 2 and these characters have their own stories. In Kidung Shalawat, Zaki and Zulfa have fewer characters and the storyline focuses on the main character, Zaki. The intertextuality that occurs in the work of the hypogram (the novel Kidung Shalawat Zaki and Zulfa by Taufiqurrahman Al Azizy) is the absorption of ideas or ideas and some other intrinsic elements.

In Ketika Cinta Bertasbih 2, a child in the Islamic religious teaching represented by Anna in getting a life partner does not go through the process of dating. Taufiqurrahman reiterated the idea of a story about the life of the kiai, the owner of the islamic boarding school, with the idea of a matchmaking story that the kiai had with children since they were still in their womb.

The plot in Ketika Cinta Bertasbih 2 is wider than Kidung Shalawat Zaki and Zulfa even though they both made the story in subtitles. Taufiqurrahman focuses more on one story character, while in Ketika Cinta Bertasbih 2 there are several other characters who have their own stories that have nothing to do with the main character. The plot in the Song Shalawat Zaki and Zulfa tells the story of Zaki to the end of the story. The plot in the Song Shalawat Zaki and Zulfa tells the story of Zaki to the end of the story. 


\section{Conclusions}

Based on the research results, it can be concluded that the novel Kidung shalawat Zaki and Zulfa has transformed with the novel Ketika Cinta Bertasbih 2 and there are several similarities and differences. The similarities that exist from these two novels are in the form of similarities in story ideas, plot, characters and characterizations, and settings. Likewise, with the differences contained in the two novels in the form of points of view, mandate. Intertextuality studies should be continued in order to confirm that literary works have an intertextual relationship.

\section{References}

Wicaksono, A. (2017). The Study of Prose Fiction. Yokyakarta: Garudhawaca.

Andari, N, W, Y. (2019). Intrinsic Elements and Moral Values in Novel Tarian Bumi Karya Oka Rusmini (2007). RETORIKA: Jurnal Ilmu Bahasa, 5(1) 40-44. doi: http://dx.doi.org/10.22225/jr.5.1.769.40-44

Nurgiyantoro, B. (2015). Teori Pengkajian Fiksi. Yogyakarta: Gadjah Mada University Press.

Shirazy, H. E. (2008). When Love Begins 2. Jakarta: Republika

Emzir \& Rohman. (2015). Theory and Teaching of Literature. Jakarta: PT Raja Grafindo Persada.

Faruk. (2013). Introduction to Sociology of Sasstra. From Genetic Structuralism to Post Mordenization. Yokyakarta: Student Library.

Gunawan, I. (2013). Qualitative Research Methods in Theory and Practice. Jakarta: Earth Literacy.

Kuswarini, P. (2016). Intertextuality Translation, Hermeneutics and Reception Aesthetics. Journal of Cultural Sciences, $4 / 1$.

Kutha, N. R. (2015). Theory, Methods, and Literary Research Techniques. Yokyakarta: Student Library.

Shirazy, H. E. (2007). When Love is tasbih (Book 2 Dwilogi of Soul Builder). Jakarta: Republika

Nurgiyantoro, B. (2013). Theory of Fiction Assessment. Yokyakarta: Gadjah Mada University Press 